\section{An in-depth look at the status of environmental financial accounting in Mexico from the point of view of stakeholder theory: myth or reality?}

Saulo Sinforoso Martínez ${ }^{1}$

Arístides Pelegrin $\mathrm{Mesa}^{2}$ (i)

\section{Abstract}

Purpose - This research project analyzes the use of the theoretical contributions regarding environmental financial accounting (EFA) by Mexican companies.

Design/methodology/approach - The methodology is divided into two sections. The first part involves a document analysis of the sustainability reports issued by 29 sustainable companies from the Mexican Stock Exchange. The second section describes the correlation between the EFA components and revenue.

Findings - The preliminary findings show that the ideas regarding social and environmental accounting written over two decades ago by Gray (1992), Laringa (1995), Moneva and Llena (1996), Bebbington (2001), and Llull (2001), among others, have been applied within the context of the Mexican economy. However, there are some theoretical gaps that will continue to make EFA a myth for emerging economies due to the lack of public policies.

Originality/value - This study identifies that the Mexican economy requires two actions in order to legitimize the stakeholder theory. First, the concepts of environmental accounting need to be applied across micro, small and medium-sized businesses. Second, the relationships among stakeholders (suppliers, customers, shareholders, etc.) need to be analyzed in the environmental reports in order to assess their level of influence on decision making. The starting point for this analysis should be the methodology applied in developed economies.

Keywords - Environmental accounting, Sustainability, Competitiveness, Decision making

1. University of Veracruz, School of Accounting, Tuxpan, Veracruz, Mexico

2. University of Guadalajara, University Center of Economic and Managerial Sciences, Zapopan, Jalisco, Mexico

How to cite:

Martínez, S., Mesa, A. (2021). An in-depth look at the status of environmental financial accounting in Mexico from the point of view of stakeholder theory: myth or reality? Revista Brasileira de Gestâo de Negócios, 23(2), firstpage-lastpage.
318

Received on:

$11 / 02 / 2019$

Approved on:

07/27/2020

Responsible Editor:

Prof. Dr. Natalia Vidal

Evaluation process:

Double Blind Review

\section{Reviewers:}

Happy Salas Fuentes; Fernando Salazar-Arrieta.

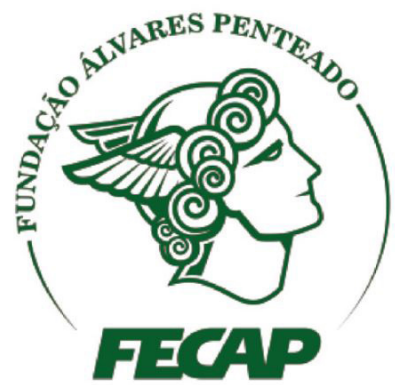

Revista Brasileira de Gestáo de Negócios

https://doi.org/10.7819/rbgn.v23i2.4107 
An in-depth look at the status of environmental financial accounting in Mexico from the point of view of stakeholder theory: myth or reality?

\section{Introduction}

Over the past 20 years, several authors (Bebbington, 2001; Gray, 1992; Larrinaga, 1995; Llull, 2001; Moneva \& Llena, 1996, among others) have stressed the need for companies to disclose environmental and social information. Decades have passed since Tua (1995) defined accounting as a science. He argued that accounting professionals have attempted to fulfill the needs of society not only by processing and presenting information. According to him, they have also contributed with new concepts and procedures related to issues that concern society.

Accounting involves non-static knowledge under constant construction (Mejía, Montilla, Montes, \& Mora, 2015). The term environmental accounting results from a series of discussions regarding how accounting can contribute to caring for natural resources so as to ensure that the needs of future generations are met. Environmental accounting identifies measures and assigns environmental costs that should be considered in commercial decisions as well as in communications between the parties of a given company (Mussa, Feku, \& Mussa, 2018). It also deals with activities, methods, recording, analysis, and the reporting of the environmental and ecological impacts of defined economic systems (Azizul, 2017). According to Larrinaga (1997, p. 960): "the criteria traditionally considered by accounting to determine the success of a company are merely based on results that ignore the social and environmental impact that companies cause. Now, with aims to move in a different direction, the idea is to create a social accounting that evaluates to what degree a company meets the social contract."

In terms of sustainability, financial information is fundamental for companies, as it assists with decisionmaking related to environmental concerns (Stefan, 2017). Financial reports are thus essential since they provide data to develop and implement actions to care for and preserve natural resources. According to Salas (2015, p. 102): "Accounting_as a means to represent economic activity—has to acknowledge, present and evaluate relevant information concerning the environmental performance of a company in the protection of the setting where it is located." This has given rise to the emergence of "specialized segments of the accounting discipline constituted of different areas: environmental financial accounting, environmental costs or environmental management, and environmental auditing" (Palma \& Cañizares, 2018, p. 137). These are quite useful in managing the environmental and operating costs of natural resources (Muralikrishna \& Manickam, 2017).

Environmental accounting has been a topic of discussion at both the national and international level. So far, numerous articles have been published that address theoretical propositions, concepts, and the importance of their application among companies. These have attracted great interest in academic discussions (Macías \& Velázquez, 2017). However, it is now time to question the professional application of environmental accounting (Bernal \& Santos, 2018) in emerging economies. In this sense, Larrinaga, Moneva, and Ortas (2019) state that it is not enough to study the impact of environmental financial accounting (EFA) in developed economies; it is also necessary to explore other perspectives, as the market economy is characterized by high uncertainty of the business environment, and the speed of development leads to the need to adapt enterprises to a dynamic market environment (Sheshukova \& Mukhina, 2018). Thus, the aim of this study is to analyze the use of EFA in sustainable companies listed on the Mexican Stock Exchange in order to question how useful the theoretical contributions are regarding the relationship between the environment and accounting reports in Mexico. Therefore, the main research question is: how has the theory generated by academics on environmental financial accounting been applied in sustainable companies listed on the Mexican Stock Exchange? This leads to the following specific questions: has there been a transition in Mexico from conventional accounting to a type of accounting that is concerned with the environment?; do theoretical proposals on environmental accounting enhance business competitiveness?; what accounts do companies use to keep records of environmental transactions?; and finally, is the impact on the Mexican economy real or a myth? These questions are addressed and discussed in this quantitative, descriptive, and correlational study on 29 sustainable companies listed on the Mexican Stock Exchange (BMV, according to its Spanish acronym), through document analysis of their 2018 and 2019 third quarter financial reports and the sustainability reports for the 2018 financial year. The study assesses the impact of EFA on the revenue of these companies. Finally, the analytic-synthetic method is applied to review the sustainability and financial reports in order to analyze the use of EFA in Mexican companies. 


\section{Literature review}

\section{I Progress in and limitations of the use of environmental financial accounting (the last 5 years)}

Llena (2008) indicates that one of the areas of environmental accounting is environmental financial accounting. Several studies have been conducted in this field over the past five years, some of which address the representation of environmental impact in accounting (Colmenares, Valderrama, \& Adriani, 2015). Others propose decision-making tools such as the environmental profit and loss account (Déniz \& Verona, 2015). This assists with the sustainable development of companies (Martinez, Jimenéz, \& Mesa, 2019), as information of this nature is important for those who manage the resources within firms (Gray, Owen, \& Adams, 1996).

Table 1 lists a few examples of recent studies on the use of environmental financial accounting around the world. These are sorted by continent and country and highlight the interest of various academics with regards to this topic.

With regards to the progress in and limitations of EFA in the business and economic environment, the findings of recent studies are reassuring. In the United Arab Emirates, the use of EFA allows companies to develop strategies for the financial market (Al-Mawali et al., 2018). For cement companies in Hungary, the reports generated by EFA are important for decision making (Fogarassy et al., 2018). In Vietnam, EFA has been useful in preventing financial risks and generating competitive advantages (La Soa, 2019). Studies conducted in the chemicals industry in South Africa show that environmental management practices assist in generating financial information for the companies listed in the stock market (Smith \& Kotzee, 2017).

The drawbacks for the implementation of EFA vary depending on the country; this could be a direction for further studies on the subject. For instance, manufacturing companies in Bangladesh need to have specific environmental accounting principles before they

Table 1

\section{Impact of the spread of environmental financial accounting around the world}

\begin{tabular}{|c|c|c|c|}
\hline Continent & Country & Author (s) & Themes under study \\
\hline \multirow[t]{4}{*}{ Asia } & India & $\begin{array}{l}\text { Kumar \& Firoz } \\
\quad(2019 b)\end{array}$ & $\begin{array}{l}\text { Dissemination and presentation of reports of certified } \\
\text { emission reductions in financial reports. }\end{array}$ \\
\hline & Bangladesh & Hossain (2019) & $\begin{array}{l}\text { Challenges for environmental accounting in manufacturing } \\
\text { companies. }\end{array}$ \\
\hline & Vietnam & La Soa (2019) & $\begin{array}{l}\text { Relationship between the practice of environmental financial } \\
\text { accounting and corporate financial risk. }\end{array}$ \\
\hline & United Arab Emirates & $\begin{array}{c}\text { Al-Mawali, Al-Sharif, } \\
\text { Rumman, Kerzan \& } \\
\text { Liu (2018) }\end{array}$ & $\begin{array}{l}\text { Relationship between EA and the elaboration of strategies in } \\
\text { the financial market. }\end{array}$ \\
\hline Europe & Hungary & $\begin{array}{l}\text { Fogarassy, Neubauer, } \\
\text { Mansur, Tangl, Oláh, \& } \\
\text { Popp (2018) }\end{array}$ & $\begin{array}{l}\text { The impact of environmental accounting on the financial } \\
\text { performance of the cement industry. }\end{array}$ \\
\hline \multirow[t]{2}{*}{ Africa } & South Africa & Smith \& Kotzee (2017) & $\begin{array}{l}\text { Environmental management accounting in the chemistry } \\
\text { industry of South Africa. }\end{array}$ \\
\hline & Algeria & $\begin{array}{l}\text { Nadjoua \& Bouselma } \\
\qquad(2016)\end{array}$ & $\begin{array}{l}\text { Challenges for the implementation of environmental } \\
\text { financial accounting in cement companies in Algeria. }\end{array}$ \\
\hline \multirow[t]{5}{*}{ America } & Argentina & $\begin{array}{l}\text { Larramendy, Tellechea, } \\
\quad \& \text { Tobes }(2018)\end{array}$ & $\begin{array}{l}\text { Environmental financial accounting applied in companies } \\
\text { listed on the Buenos Aires Stock Exchange. }\end{array}$ \\
\hline & Brazil & $\begin{array}{l}\text { Cunha \& Moneva } \\
\qquad(2018)\end{array}$ & $\begin{array}{l}\text { The processes for the elaboration of environmental reports in } \\
\text { sustainable companies. }\end{array}$ \\
\hline & Cuba & $\begin{array}{l}\text { Albuerne \& Venereo } \\
\qquad(2017)\end{array}$ & Environmental financial accounting in the rum industry. \\
\hline & Ecuador & Vilela (2017) & $\begin{array}{l}\text { Use of environmental financial accounting in the agriculture } \\
\text { industry. }\end{array}$ \\
\hline & Mexico & $\begin{array}{l}\text { Gámez, Joya, \& García } \\
\text { (2017) }\end{array}$ & Analysis of environmental financial budgeting. \\
\hline
\end{tabular}


can implement EFA (Hossain, 2019). In Ecuador, the lack of terminology has been an obstacle for its development in agricultural companies (Vilela, 2017). For other countries, such as Cuba, there are a large number of theoretical proposals that could be the basis for the implementation of EFA in companies where it is unknown, such as in rum businesses (Albuerne $\&$ Venereo, 2017). In the case of the cement industry in Algeria, the obstacles for companies to implement EFA are external, such as the lack of legal texts to force companies to provide and issue financial reports related to their environmental performance (Nadjoua \& Bouselma, 2016).

Other findings regarding the application of EFA are evidence of how useful it is for the business sector. For instance, companies listed on the Buenos Aires Stock Exchange in Argentina tend to disclose environmental information, thus proving their social responsibility (Larramendy, Tellechea, \& Tobes, 2018). In India, some companies keep accounting records of carbon emissions, which allows them to increase their value (Kumar \& Firoz, 2019b). In the case of chemicals and oil companies in Brazil and Spain, transparency and legitimacy of their activities are the main reasons why they elaborate sustainability reports to keep stakeholders informed (Cunha \& Moneva, 2018).

\subsection{Stakeholder theory from the perspective of Mexican companies}

Stakeholder theory, according to Freeman (1984), considers the interested parties within a company as members connected by a common cause. This theory is included in the ethical framework of the company (Carroll, 1989), so that all parties participate in the decision-making process (Martínez, Carbonell, \& Agüero, 2006). For Freeman (1984), an organization is a group of parties known as stakeholders. These are shareholders, employees, investors, suppliers, customers, and society in general (Uribe \& Requena, 2013), who all work together to create a successful business (Freeman, 2010). In this sense, communication and interaction among stakeholders make an important contribution in the process of achieving company goals (Schvarstein, 2010). Thus, the information disclosed by a company is fundamental to devising the best corporate strategy (Hyo-Sook, 2011) to address concerns such as caring for and preserving natural resources (Barrios \& Enrique, 2018; Castañeda, 2017; Contreras, Talero, \& Escobar, 2020).
However, the main objective of this theory is not to focus on the information, but to ensure that all stakeholders become involved in issues concerning the environment; the aim is to strengthen business decisions regarding environmental impact (Carrasco, Correa, \& Larrinaga, 1999). With this in mind, "accounting and the accounting profession have to participate in fulfilling the needs of all stakeholders, as they offer information to collaborate in environmental management through different functions" (Llena, 2008, p. 126). In Mexico, environmental financial information has been disclosed through sustainability reports; thus, accounting has become the instrument that companies have at hand to provide information for stakeholders (Gray, Owen, \& Adams, 1996).

This theory became relevant for Mexican companies in 2011, when the Mexican Stock Exchange created the sustainable IPC (the acronym stands for "index of prices and quotations" in Spanish). Its application is essential, as "environmental reporting is becoming increasingly important in the value creation processes of firms" (Kumar $\&$ Firoz, 2019b, p. 1). The sustainable IPC aims to create an index of Mexican firms that show a commitment to the environment. These businesses are known as sustainable companies. The concept is proof of the impact that theoretical proposals regarding sustainable development have on business practices.

The sustainable IPC started with 23 companies. By 2019, the number had increased to 29 , according to the BMV report of January 2020. These are from sectors such as telecommunication services, industrials, materials, consumer discretionary and services, consumer staples, healthcare, energy, and financial services. The companies have to issue a yearly report to inform stakeholders and owners about the environmental impact resulting from their business practices. This is proof of the implementation of stakeholder theory. The reports disclose information generated by environmental financial accounting which, as Llull (2001, p. 117) highlights, includes "estimates, records, and information regarding environmental assets, liabilities, expenditure, income, contingencies, and provisions." After years of research on environmental accounting, it is time to investigate whether it helps Mexican companies to achieve sustainability. In this regard, several authors (Gray, 1992; Larrinaga, 1995; Parodi, 2010, etc.) affirm that companies do increase their competitiveness in the long term by including environmental aspects in their accounting reports. 


\section{Methodology}

This research uses a quantitative approach. It is based on statistical reports issued by the Mexican Stock Exchange. It is a descriptive study on environmental financial accounting and its use in companies' financial and sustainability reports. It is also correlational, as it measures the impact of EFA on the revenue of the companies investigated. It is cross-sectional, as it is based on the sustainability reports for the 2018 financial year, which were officially published in January of 2020; as well as the financial reports for the third quarters of 2018 and 2019.

The analytic-synthetic method is applied to analyze the sustainability and financial reports in order to assess the use of EFA.

The subjects of this study are the 29 companies listed in 2019 on the Mexican Stock Exchange in the sustainable IPC. The following paragraphs describe the methodology:

Phase 1. Review international case studies conducted over the last five years on the use of environmental financial accounting.

Phase 2. Analyze the theoretical contributions provided by innovative and contemporary authors concerning the role of environmental financial information in decision making.

Phase 3. Classify sustainable companies by sector. This assists in identifying the leading sector in the sustainable market.

Phase 4. Analyze sustainability reports issued by the BMV's sustainable companies for the 2018 financial year. The aim is to identify environmental activities, social and/or environmental reports, and the recording of environmental provisions, liabilities, expenditure, and investments.

Phase 5. Carry out a comparative analysis of the revenue during the third quarters of 2018 and 2019 based on the financial reports of the BMV.

Phase 6. Analyze the correlation between environmental financial accounting and fluctuations in revenue.

\section{I Data collection method and instrument}

The method and the instrument used for the data collection throughout this research study were document analysis and the data collection sheet, respectively. The tools employed to interpret the information were Microsoft Excel and the Statistical Package for the Social Sciences (SPSS). The information sources were the 2018 sustainability reports and the 2018 and 2019 financial reports, which can be accessed using the BMV's digital platform (See Table 2).

The description of the information in Table 2 is as follows:

$\mathrm{V}_{1}$. Sustainable companies: A list of companies was downloaded from the BMV's digital platform. The data collection sheet was used to select the companies listed as sustainable IPC. These were classified in Microsoft Excel tables.

$\mathrm{V}_{2}$. Environmental accounting: The data collection sheet was used to identify the use of environmental aspects in the companies' sustainability reports. Microsoft Excel tables were used to present the following indicators of $\mathrm{V}_{2}$ :

$\mathrm{V}_{2.1}:$ Environmental activities report;

Table 2

Data collection method and instrument used for analyzing the use of environmental financial accounting in sustainable companies listed on the Mexican Stock Exchange.

\begin{tabular}{|c|c|c|c|c|}
\hline Variables in the study & Method & $\begin{array}{l}\text { Instrument for data } \\
\text { collection }\end{array}$ & Tools for data analysis & Sources of information \\
\hline $\mathrm{V}_{1}$.Sustainable companies & Document analysis & $\begin{array}{l}\text { Data recording } \\
\text { (Appendix A) }\end{array}$ & Microsoft Excel & $\begin{array}{l}\text { BMV's digital platform: } \\
2018 \text { sustainability } \\
\text { reports }\end{array}$ \\
\hline $\begin{array}{l}\mathrm{V}_{2 .} \text { Environmental } \\
\text { accounting }\end{array}$ & & & Microsoft Excel & $\begin{array}{c}\text { BMV's digital platform: } \\
2018 \text { sustainability } \\
\text { reports }\end{array}$ \\
\hline $\begin{array}{l}\mathrm{V}_{3 .} \text { Revenue vs } \\
\text { Environmental } \\
\text { accounting }\end{array}$ & & & $\begin{array}{l}\text { Statistical Package for the } \\
\text { Social Sciences (SPSS) }\end{array}$ & $\begin{array}{l}\text { BMV's digital platform: } \\
2019 \text { and } 2018 \text { financial } \\
\text { reports. }\end{array}$ \\
\hline
\end{tabular}

$\mathrm{V}_{1}=$ Variable $1, \mathrm{~V}_{2}=$ Variable $2, \mathrm{~V}_{3}=$ Variable 3

Source: Elaborated by the author. 
$\mathrm{V}_{2.2}: \quad$ Environmental provisions and liabilities;

$\mathrm{V}_{2.3}: \quad$ Environmental expenditure and investment;

$\mathrm{V}_{2.4}: \quad$ Environmental and/or social balance.

$\mathrm{V}_{3}$. Revenue vs environmental accounting: The fluctuations in revenue during the third quarters of 2018 and 2019 were correlated to the aspects of environmental accounting (environmental activities reports, social and/or environmental balance, as well as environmental provisions, liabilities, expenditure, and investment). The Statistical Package for the Social Sciences (SPSS) was used on the BMV's financial reports to correlate the variables. The confidence level was 95\% with a 5\% margin of error. The Pearson's correlation coefficient was used for the analysis.

\section{Findings: presentation and analysis}

The actions taken by sustainable companies are evidence of the implementation of stakeholder theory in the Mexican economy. These companies are listed in Table 3 by sector and include America Movil, Cemex, Grupo Financieros Banorte, and Grupo Elektra. By 2019, a total of 29 companies were taking actions to maintain a balance between economic, environmental, and social aspects.

Chart 1 shows the companies, classified by sector, that apply stakeholder theory in their environmental reports. Most of them (28\%) specialize in consumer staples such

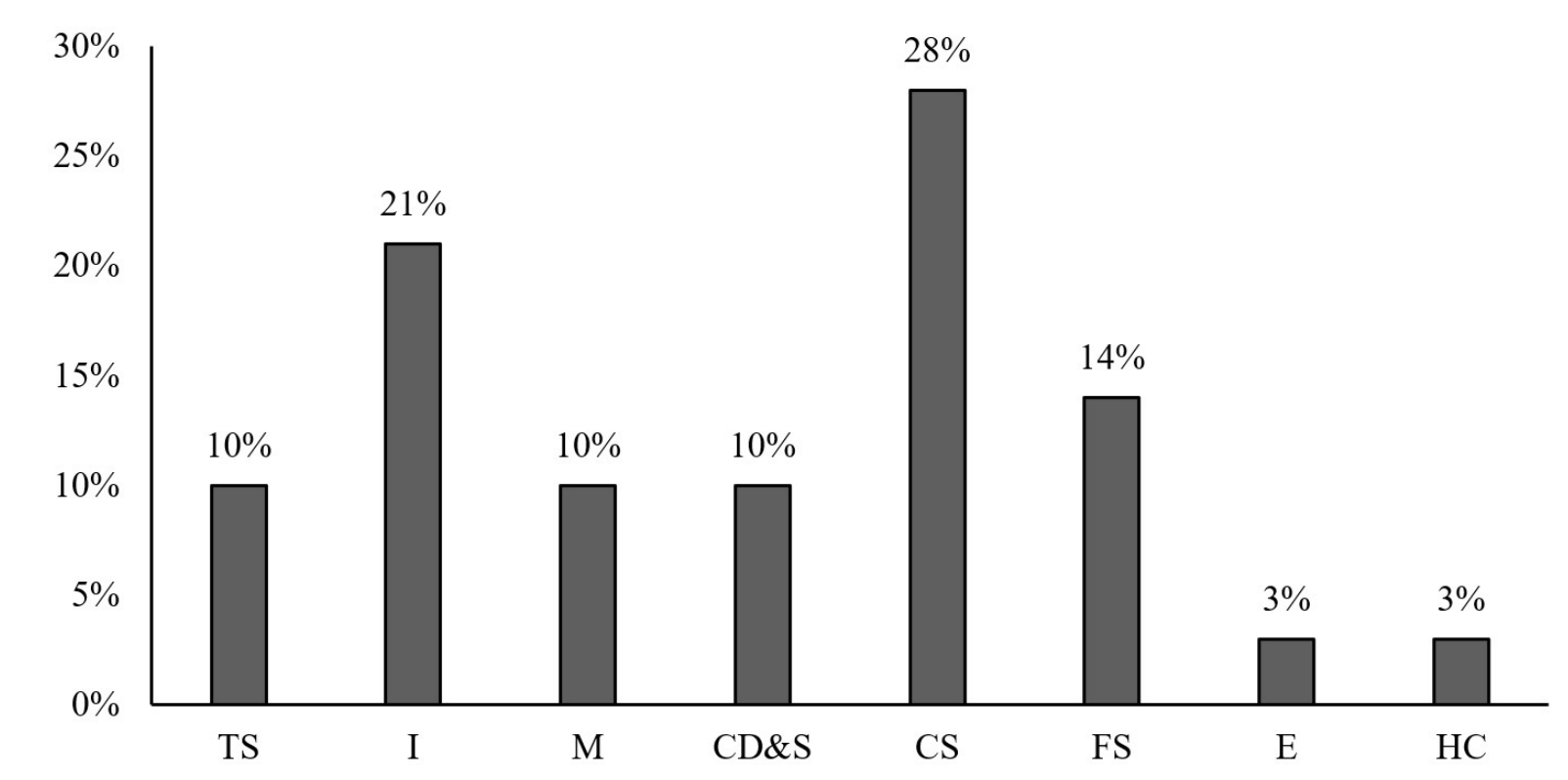

Chart 1. Business sectors of the sustainable companies listed on the Mexican Stock Exchange in

2019 as food, drinks, and tobacco. Infraestructura Energetica Nova and Genomma Lab Internacional represent a 3\% minority that specializes in the energy and healthcare sector, respectively. According to Chart 1, over a fifth (21\%) of the companies belong to the industrial sector, including Grupo Aeroportuario del Sureste, ALFA, Grupo Aeroportuario del Centro Norte, Corporación Inmobiliaria VESTA, Controladora Vuela Compañía de Aviacion, and Orbia Advance Corporation (See Table 3).

Chart 2 shows that all sustainable companies listed on the Mexican Stock Exchange in 2018 issued reports disclosing the activities carried out to benefit the environment. This is proof of the use of stakeholder theory. In terms of the elements described by Llull (2001), 93\% of the companies include in their reports quantitative and qualitative information with regards to expenditure and investments to care for and preserve natural resources. A smaller number (69\%) provide users with a social or environmental report. Finally, only $28 \%$ of the companies show a commitment to the environment by using provisions or contingent liability accounts. These accounts keep records of the potential cash expenditure resulting from the environmental damage caused by company practices.

Authors such as Gray (1992), Larrinaga (1995), and Parodi (2010) have stated that companies that include information on environmental impact in their reports increase their competitiveness in the long term. Furthermore, recent studies, such as those carried out in 
Table 3

Sustainable companies listed on the Mexican Stock Exchange in 2019

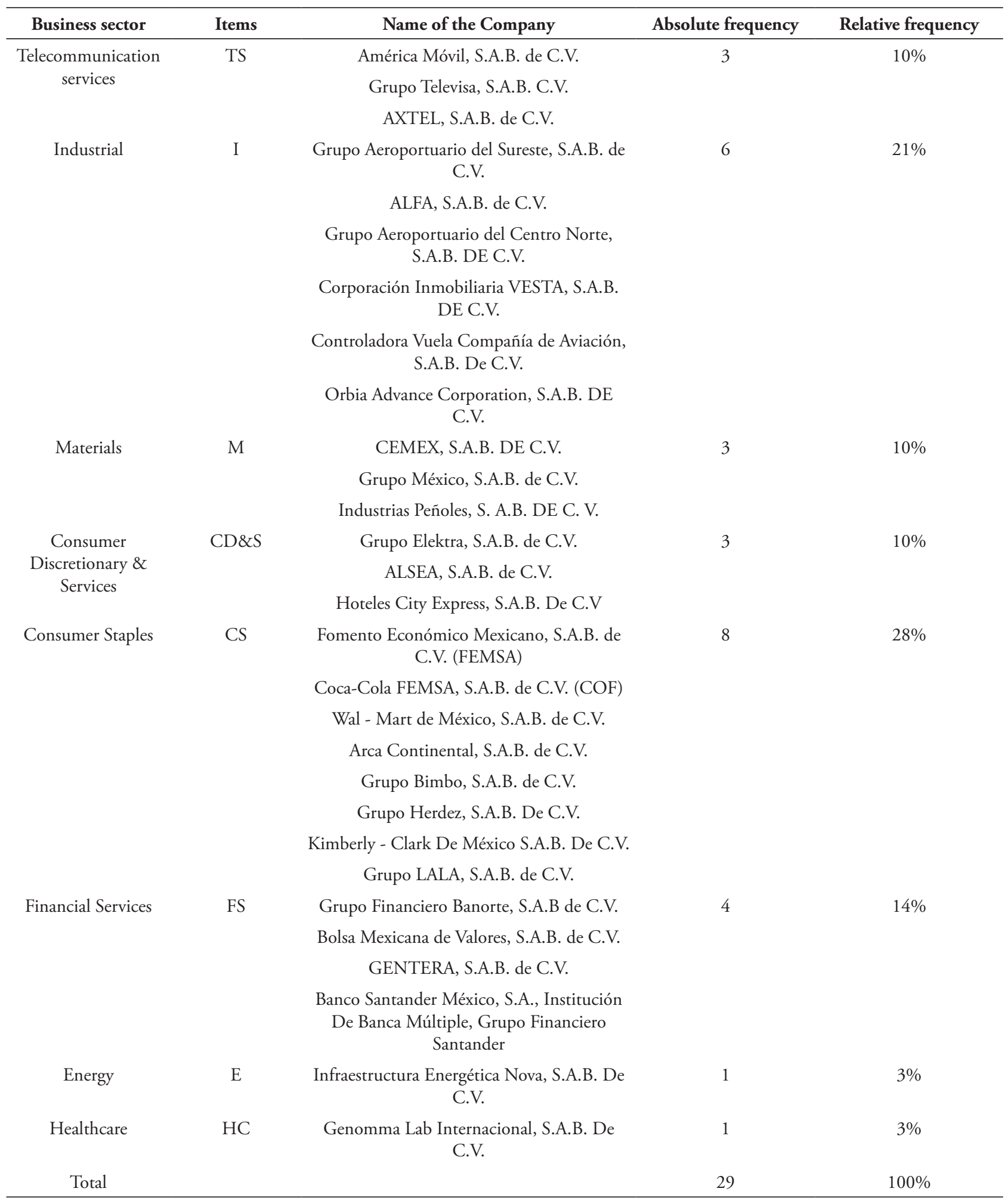

Greek industry, support this statement by pointing out the positive correlation that exists between financial and environmental performance (Alexopoulos, Kounetas,
\& Tzelepis, 2018). Part of this investigation focuses on measuring the impact that the use of EFA has on the revenue of sustainable companies established in Mexico. 


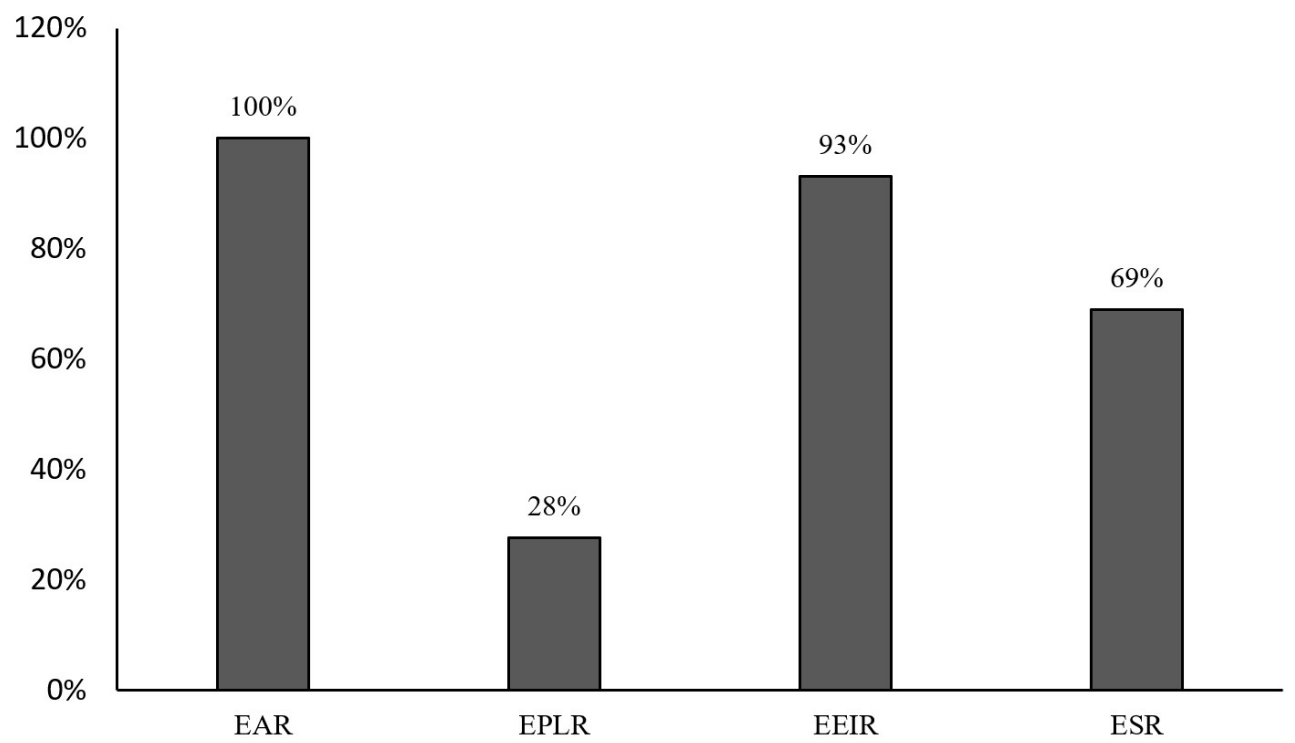

Chart 2. Application of the aspects of environmental financial accounting by sustainable companies listed on the Mexican Stock Exchange in 2018

Note. EAR $=$ Environmental activities report, EPLR $=$ Environmental provisions and liabilities report, EEIR = Environmental expenditure and investment report, ESR = Environmental/social report.

Table 4 displays a comparative analysis of revenue in the third quarters of 2018 and 2019. The findings show a positive fluctuation as 25 out of the 29 companies studied saw an increase in revenue compared to the same quarter of the previous year (the value assigned in Table 4 is 1).

Table 4 provides a summary of all the companies that apply stakeholder theory, the aspects of environmental accounting, and the fluctuations in revenue between the third quarters of 2018 and 2019.

The data in Table 5 show that reports on environmental activities and on environmental investment and expenditure are the two aspects of EFA that are most frequently applied in the elaboration of sustainability and financial reports. In this regard, there is evidence of accounting reports on environmental expenditure, investment, provisions, and liabilities; however, there are no environmental accounts as such in the financial reports. In fact, the amounts are included in the conventional accounts. This presents an obstacle for decision makers and stakeholders to identify them. For most of the companies (86\%), there was an increase in revenue between the third quarters of 2018 and 2019.

Table 6 presents the findings of the correlational analysis between the aspects of environmental accounting and the revenue of the BMV's sustainable companies.

\section{I Environmental expenditure and investments $\left(V_{2.3}\right)$ vs revenue $\left(V_{3}\right)$}

The Pearson's correlation shows that environmental expenditure and investments have a slight negative relationship with revenue (-0.109); when expenditure is allocated for the acquisition of environmental equipment, the revenue of sustainable companies decreases slightly. However, "investing in clean technologies initially means a great investment that, with time, will result in great economic benefits, such as savings on raw materials, solid waste production, energy, or water. This is because environmental investments are meant for the long term" (Campos, 2009, p. 248). Expenditure and investments contribute to the sustainability of a company; they guarantee that the company maintains its position in both the national and international market as they allow for "the development of new markets, products and production processes" (Hutchinson, 1992).

\subsection{Contingent provisions and liabilities $\left(V_{2.2}\right)$ vs revenue $\left(V_{3}\right)$}

According to Tua (2001), companies have to provide environmental provisions whenever it is required by law or by a contract, as well as when the company has assumed that responsability or when the business states that it will prevent, reduce, or repair certain damage to 
Table 4

\section{Comparative analysis of revenue in the third quarters of 2018 and 2019 of the BMV's sustainable IPC companies}

\begin{tabular}{|c|c|c|c|c|c|}
\hline Business sector & $\begin{array}{c}\text { Aspects of Environmental } \\
\text { Financial Accounting/ } \\
\text { Companies }\end{array}$ & $\begin{array}{c}\text { Revenue } 2019 \text { Third } \\
\text { Quarter }\end{array}$ & $\begin{array}{c}\text { Revenue } 2018 \text { Third } \\
\text { Quarter }\end{array}$ & Variation $(+)$ & Variation (-) \\
\hline \multirow[t]{3}{*}{ TS } & América Móvil & $248,425,505.00 \mathrm{mxn}$ & $247,935,745.00 \mathrm{mxn}$ & 1 & \\
\hline & Grupo Televisa & $25,786,149.00 \mathrm{mxn}$ & $25,033,234 \mathrm{mxn}$ & 1 & \\
\hline & AXTEL & $3,167,232.00 \mathrm{mxn}$ & $3,139,869.00 \mathrm{mxn}$ & 1 & \\
\hline \multirow[t]{6}{*}{ I } & $\begin{array}{l}\text { Grupo Aeroportuario del } \\
\text { Sureste }\end{array}$ & $4,106,266.00 \mathrm{mxn}$ & $3,682,047.00 \mathrm{mxn}$ & 1 & \\
\hline & ALFA & $83,842,066.00 \mathrm{mxn}$ & $93,940,201.00 \mathrm{mxn}$ & & 0 \\
\hline & $\begin{array}{l}\text { Grupo Aeroportuario del } \\
\text { Centro Norte }\end{array}$ & $2,155,384.00 \mathrm{mxn}$ & $1,966,564 \mathrm{mxn}$ & 1 & \\
\hline & $\begin{array}{c}\text { Corporación Inmobiliaria } \\
\text { VESTA }\end{array}$ & $35,826.00$ usd & $33,822.00$ usd & 1 & \\
\hline & $\begin{array}{l}\text { Controladora Vuela } \\
\text { Compañía de Aviación }\end{array}$ & $9,501,756.00 \mathrm{mxn}$ & $7,316,075.00 \mathrm{mxn}$ & 1 & \\
\hline & Orbia Advance Corporation & $1,746,875.00$ usd & $1,785,291.00$ usd & & 0 \\
\hline \multirow[t]{3}{*}{ M } & CEMEX & $3,494,091.00$ usd & $3,636,210.00$ usd & & 0 \\
\hline & Grupo México & $2,793,883.00$ usd & $2,594,524.00$ usd & 1 & \\
\hline & Industrias Peñoles & $1,103,664.00$ usd & $1,048,186.00$ usd & 1 & \\
\hline \multirow[t]{3}{*}{ CD\&S } & Grupo Elektra & $29,733,117.00 \mathrm{mxn}$ & $25,490,119 \mathrm{mxn}$ & 1 & \\
\hline & ALSEA & $14,490,497.00 \mathrm{mxn}$ & $11,375,395.00 \mathrm{mxn}$ & 1 & \\
\hline & Hoteles City Express & $811,775.00 \mathrm{mxn}$ & $741,116.00 \mathrm{mxn}$ & 1 & \\
\hline \multirow[t]{8}{*}{ CS } & $\begin{array}{l}\text { Fomento Económico } \\
\text { Mexicano (FEMSA) }\end{array}$ & $130,470,010.00 \mathrm{mxn}$ & $118,371,443.00 \mathrm{mxn}$ & 1 & \\
\hline & Coca-Cola FEMSA (COF) & $48,698,552.00 \mathrm{mxn}$ & $44,148,103.00 \mathrm{mxn}$ & 1 & \\
\hline & Wal - Mart de México & $155,018,693.00 \mathrm{mxn}$ & $147,767,841.00 \mathrm{mxn}$ & 1 & \\
\hline & Arca Continental & $42,415,195.00 \mathrm{mxn}$ & $40,556,716.00 \mathrm{mxn}$ & 1 & \\
\hline & Grupo Bimbo & $74,965,171.00 \mathrm{mxn}$ & $72,646,378.00 \mathrm{mxn}$ & 1 & \\
\hline & Grupo Herdez & $5,569,282.00 \mathrm{mxn}$ & $5,203,789.00 \mathrm{mxn}$ & 1 & \\
\hline & $\begin{array}{c}\text { Kimberly - Clark De } \\
\text { México }\end{array}$ & $10,399,724.00 \mathrm{mxn}$ & $9,896,553.00 \mathrm{mxn}$ & 1 & \\
\hline & Grupo LALA & $18,984,001.00 \mathrm{mxn}$ & $18,757,695.00 \mathrm{mxn}$ & 1 & \\
\hline \multirow[t]{4}{*}{ FS } & Grupo Financiero Banorte, & $\begin{array}{c}84,563,000,000.00 \\
\operatorname{mxn}^{\text {IA }}\end{array}$ & $\begin{array}{c}73,444,000,000.00 \\
\operatorname{mxn}{ }^{\text {IA }}\end{array}$ & 1 & \\
\hline & Bolsa Mexicana de Valores & $933,764.00 \mathrm{mxn}$ & $871,846.00 \mathrm{mxn}$ & 1 & \\
\hline & GENTERA & $16,802,536,063.00 \mathrm{mxn}$ & $\begin{array}{c}15,412,072,117.00 \\
\operatorname{mxn}\end{array}$ & 1 & \\
\hline & $\begin{array}{l}\text { Banco Santander México, } \\
\text { S.A., Institución De Banca } \\
\text { Múltiple, Grupo Financiero } \\
\text { Santander }\end{array}$ & $\begin{array}{c}30,465,000,000.00 \\
\operatorname{mxn}^{\mathrm{IA}}\end{array}$ & $\begin{array}{c}\$ 28828000,000.00 \\
\operatorname{mxn}^{\text {IA }}\end{array}$ & 1 & \\
\hline $\mathrm{E}$ & $\begin{array}{c}\text { Infraestructura Energética } \\
\text { Nova }\end{array}$ & $355,098.00$ usd & $408,032.00$ usd & & 0 \\
\hline \multirow[t]{2}{*}{$\mathrm{HC}$} & Genomma Lab Internacional & $3,077,304.00 \mathrm{mxn}$ & $2,734,825.00 \mathrm{mxn}$ & 1 & \\
\hline & \multicolumn{2}{|c|}{ Total $=29$ companies } & & 25 & 4 \\
\hline
\end{tabular}

Note $^{\mathrm{IA}}=$ Estimated revenue, $\mathrm{mxn}=$ Mexican currency, $\mathrm{USD}=$ dollars, $1=$ positive fluctuation, $0=$ negative fluctuation

the environment. In the case of Mexican companies, $28 \%$ have environmental provisions and liabilities. When these accounts are correlated with revenue, the resulting relationship is -0.424 ; this means that these accounts cause a decrease in revenue. However, they also help companies to maintain their position in the market in the long term by avoiding fees, sanctions, or business closures. This supports the argument by Parodi (2010), who states that disregarding environmental externalities results in incomplete accounting information. As a consequence, 
Table 5

Quantitative summary of the application of stakeholder theory, the aspects of environmental accounting, and the fluctuation in revenue between the third quarters of 2018 and 2019 for the BMV's sustainable IPC companies

\begin{tabular}{|c|c|c|c|}
\hline Aspects & Concepts of analysis & Absolute frequency & Relative frequency \\
\hline \multirow[t]{2}{*}{ Stakeholder Theory } & Environmental activities report & 29 & $100 \%$ \\
\hline & $\begin{array}{c}\text { Environmental provisions and } \\
\text { liabilities }\end{array}$ & 8 & $28 \%$ \\
\hline $\begin{array}{l}\text { Aspects of environmental } \\
\text { financial accounting }\end{array}$ & $\begin{array}{c}\text { Environmental expenditure and } \\
\text { investment }\end{array}$ & 27 & $93 \%$ \\
\hline \multirow{3}{*}{$\begin{array}{l}\text { Revenue fluctuations (2018 vs } \\
\text { 2019) }\end{array}$} & Environmental/Social Report & 20 & $69 \%$ \\
\hline & Positive & 25 & $86 \%$ \\
\hline & Negative & 4 & $14 \%$ \\
\hline
\end{tabular}

Table 6

\section{Correlation between the aspects of environ- mental accounting and the revenue of the BMV's sustainable companies}

\begin{tabular}{cc}
\hline Aspects of environmental accounting $\left(\mathbf{V}_{2}\right)$ & Revenue $\left(\mathbf{V}_{3}\right)$ \\
\hline Environmental activities reports $\left(\mathrm{V}_{2.1}\right)$ & 0 \\
Environmental provisions and liabilities $\left(\mathrm{V}_{2.2}\right)$ & -0.424 \\
Environmental expenditure and investment $\left(\mathrm{V}_{2.3}\right)$ & -0.109 \\
Environmental/Social Report $\left(\mathrm{V}_{2.4}\right)$ & -0.268 \\
\hline
\end{tabular}

Note. Source: Elaborated by the authors with information retrieved from the BMV from 2018 and 2019. Data processed using the SPSS. Significance level $=0.05$

he adds, companies can lose competitiveness in the long term since they rely on the environment as a means to increase efficiency (Nijkamp, Rodenburg, \& Verhoef, 1999) and "to boost their reputation and position in the market” (Claver, López, \& Molina, 2007, p. 716).

\section{$4 \cdot 3$ Social/environmental report $\left(V_{2.4}\right)$ vs revenue $\left(V_{3}\right)$}

The practices of a company in terms of social responsability constitute an intangible asset. Due to the increase in accounting and social information, the social report is now considered to be a financial account in itself (Tamayo \& Ruiz, 2018). This tool assists with decision making concerning caring for natural resources, which translates into strategies funded by businesses. These strategies cause a decrease in revenue; thus, the relationship between these variables is negative $(-0.268)$. However, these reports allow decision makers to analyze further actions and new goals for upcoming years. This enhances sustainability in the company and provides an instrument for analysis in socially responsible management. Thus, the social report assists with the difficult task of maintaining a balance between economic viability and social responsability. Essentially, all companies depend on an appropriate interaction with the surrounding environment in order to survive (Colina \& Senior, 2008); therefore, the use of social reports in sustainable Mexican companies contributes to competitiveness.

\subsection{Environmental activities report $\left(V_{2.1}\right)$ vs revenue $\left(V_{3}\right)$}

There is no correlation between these two variables since all of the BMV's sustaniable IPC companies are required to present yearly sustainability reports. Table 3 shows that $100 \%$ of the companies studied comply with this requirement. Environmental activities reports are evidence of the application of stakeholder theory. The analysis shows how stakeholders are involved in caring for and preserving natural resources. Essentially, these reports show some of the companies' environmental actions.

\subsection{EFA $\left(V_{2}\right)$ vs revenue $\left(V_{3}\right)$}

In general, the correlation between EFA and the revenue of the companies listed on the BMV is negative, given the money allocated for environmental expenditure, investment, provisions, liabilities, etc. However, this generates economic benefits in the long term as companies expand into new markets, thus increasing their earnings. This is suggested by Alba Aguilar, New Markets Director of the Mexican Stock Exchange, during an interview in 2019: "Businesses that participate in environmentally 
responsible practices show a level of growth that the rest of the companies cannot achieve. These companies can access different financing options such as the new class of tags for assets" (Rivera, 2019).

Environmental financial accounting (EFA) is evidence of the use of stakeholder theory as it allows managers to take specific actions to care for and preserve natural resources. In the case of companies not listed on the Mexican Stock Exchange, the lack of public policies or regulations to enforce the implementation of EFA in accounting reports represents an obstacle for the application of stakeholder theory. This results in competitive disadvantages in terms of sustainability, which supports the argument by Kumar and Kiroz (2019a), who state that policies based on voluntary environmental reporting have a positive relationship with the size of a business.

Some companies include environmental information in their financial reports through the accounts used for conventional accounting such as expenditure, investment, liabilities, provisions, etc. This makes it difficult for stakeholders to identify and interpret the data. According to Deegan (2013), as quoted in the paper by Bernal and Santos (2018, p. 2016): "the way the elements in financial reports such as assets, liabilities, equity, income, expenditure, etc. are defined makes it hard to adapt them to environmental financial accounting." This highlights the fact that companies who intend to follow the sustainability framework need to propose and apply a chart of environmental accounts.

It is essential to implement environmental accounting among economic entities in order to achieve sustainable development and financial benefits in the long term (Ionescu, 2017). The lack of a chart of environmental accounts results from the nonstandardization of environmental financial reports. Companies should get involved and "design plans of environmental accounts to make environmental financial information more accessible" (Garrido, 2019, p. 100). Accountants have to be creative in the elaboration and design of such accounts (Deegan, 2013) and employ the scientific methods and research techniques as a starting point (Albuerne \& Venereo, 2017). The chart of environmental accounts for companies listed on the Mexican Stock Exchange consolidates the application of stakeholder theory as it standardizes environmental accounting reports and allows stakeholders to better understand the data.
Regardless of the size of the business, environmental financial accounting has to be applied at all levels. In Mexico, it is essential to introduce the contributions of EFA in micro, small, and medium-sized businesses. Even though these represent $95 \%$ of the businesses operating in the national economy, there is a lack of theoretical proposals in this sector. Within the framework of sustainable development, environmental accounting reports should be mandatory, not voluntary. If the goal is to transition to a "green economy," accounting reports are essential in decision making.

\section{Conclusion}

EFA started 25 years ago as a series of theoretical proposals by advocates of social and environmental accounting (Bebbington, 2001; Gray, 1992; Larrinaga, 1995; Moneva \& Llena, 1996; among others), and now, in 21st-century Mexico, its application is a reality. EFA started in developed economies and has been moving into emerging economies during the past 10 years, according to Larrinaga, Moneva, and Ortas (2019, p. 12): "there are voices that are eager to bring different perspectives to the foreground, particularly from emerging economies." The inspiration for this study emerges from the idea that studies conducted in first-world countries could provide numerous perspectives regarding the application of environmental accounting (Déniz, Verona, \& De la Rosa, 2019).

In the Mexican economy, stakeholder theory became more relevant as the BMV's sustainable companies started to apply it. It is based on a normative-ethical point of view. However, there are two main actions to consider in order to achieve its legitimization. One is to introduce the contributions of environmental accounting in micro, small, and medium-sized businesses. These companies are not listed in the stock market but account for a significant number of businesses in the Mexican economy. The second is to analyze the relationship among stakeholders (suppliers, customers, shareholders, etc.) in the environmental reports of Mexican businesses in order to assess their level of influence in decision making, "as the more integrated the stakeholders of a company are, the better the managers can interpret the environment in order to enhance competitiveness" (Claver, López, \& Molina, 2007, p. 724). For this, it is essential to carry out studies based on the methodology applied in developed economies as this allows different 
perspectives to be developed (Déniz, Verona, \& de la Rosa, 2019).

EFA causes a negative impact on the revenue of the BMV's sustainable companies; however, they need it in order to maintain their position in the market in the long term. In Mexico, its application started in the companies listed on the Mexican Stock Exchange. The telecommunications and materials sectors show better application of the aspects of environmental financial accounting, as well as of stakeholder theory. Two accounting standards are used when recording environmental impact: International Accounting Standard (IAS) 37, Provisions, Contingent Liabilities, and Contingent Assets, which is used to keep records of environmental actions; and International Financial Reporting Standard (IFRS) 16, Property, Plant, and Equipment, which is applied to keep accounting records of environmental equipment. Given the characteristics of conventional accounting, both provide a limited understanding of environmental concerns.

The market economy is characterized by high uncertainty in the business environment and rapid development. This leads to the need to adapt enterprises to a dynamic market environment (Sheshukova \& Mukhina, 2018). Thus, it is necessary for sustainable companies listed on the BMV to use environmental accounting standards to homogenize their environmental reports, as there is a positive relationship between business quality and the type of environmental disclosure (Al-Shaer, Salama, \& Toms, 2017). This will ultimately allow companies to transition to an ecological civilization, as is the case of China (Margerison, 2019).

Finally, in order to encourage the BMV's sustainable companies to apply stakeholder theory through environmental financial accounting, they need to adopt what Castaneda (2017) calls an "environmental mindset," since "the better companies are able to identify environmental expenditure, the more access they will have to information that will allow them to make decisions regarding environmental management" (Cañizares, 2015, p. 20). It is also essential to develop public policies in order to encourage businesspeople to implement EFA. There are theoretical gaps for its application that will continue to make EFA a myth in Mexico. One example is the lack of a chart of environmental accounts that could standardize the presentation of environmental impact in basic financial reports. This would allow companies to inform stakeholders about environmental performance in economic terms (Correa, García, \& García, 2018).

\section{References}

Albuerne, M., \& Venereo, N. (2017). La contabilidad y la actividad medio ambiental de la industria ronera en Cuba: Caso de estudio empresa mixta Havana Club International S.A-Ronera San José. Contabilidad y Negocios, 12(24), 6-18. Retrieved from http://revistas. pucp.edu.pe/index.php/contabilidadyNegocios/article/ view/19780/19836

Alexopoulos, I., Kostas, K., \& Tzelepis, D. (2018). Environmental and financial performance. Is there a win-win or a win-loss situation? Evidence from the Greek manufacturing. Journal of Cleaner Production, 197(1), 1275-1283. Retrieved from https://doi.org/10.1016/j. jclepro.2018.06.302

Al-Mawali, H., Al Sharif, A., Rumman, G. M. A., Kerzan, F., \& Liu, G. (2018). Environmental strategy, environmental management accounting and organizational performance: Evidence from The United Arab Emirates Market. Journal of Environmental Accounting and Management, 6(2), 105-114. DOI: 10.5890/JEAM.2018.06.002

Al-Shaer, H., Salama, A., \& Toms, S. (2017). Comités de auditoría y calidad de la información financiera. Journal of Applied Accounting Research, 18(1), 2-21. Retrieved from https://doi.org/10.1108/JAAR-10-2014-0114

Azizul, M. (2017). Environmental accounting. In Poff, D. C. \& Michalos, A.C. (Ed.). Encyclopedia of Business and Professional Ethics, (pp. 1-3), Cham, Switzerland: Springer. DOI: 10.1007/978-3-319-23514-1_215-1

Barrios, E. \& Enrique, A. M. (2018). Responsabilidad social corporativa estudio sobre la identificación y clasificación de los stakeholders. aDResearchESIC, 17(17), 90-109. DOI: 10.7263/adresic-017-02

Bebbington, J. (2001). Sustainable development: A review of the international development, business and accounting literature. Accounting Forum, 25(2), 128-157. DOI: 10.1111 / 1467-6303.00059

Bernal, M. \& Santos, E. (2018). Una mirada a la contabilidad ambiental: Postulados y retos. Contaduría Universidad de Antioquia, 1(73), 199-209. DOI: https:// doi.org/10.17533/udea.rc.n73a08 
Bolsa Mexicana de Valores. (2020). Reporte de sustentabilidad. México. https://www.bmv.com.mx/es/Grupo_BMV/ Reporte_de_sustentabilidad

Campos, N. (2009). La inversión ambiental en las empresas. El cuaderno, 3(6), 235-249. Retrieved from https://dialnet.unirioja.es/revista/12079/A/2009

Cañizares, M. (2015). Procedimiento para cuantificar los costos de las actividades ambientales en la gestión de sostenibilidad del recurso agua potable (Doctoral dissertation, University of La Habana, La Habana, Cuba)

Carrasco, F., Correa, C., \& Larrinaga, C. (1999). Información y gestión medioambiental: Una reflexión sobre los factores de motivación, proceso de desarrollo de informes e influencia de los Stakeholders en las empresas del sector eléctrico. Reunión sobre Investigación en Contabilidad Social y Medioambiental.

Carroll, A. B. (1989). Business and society: Ethics and stakeholder management. Cincinnati, United States: SouthWestern Thomson Learning.

Castańeda, V. M. (2017). La contabilidad como una disciplina social y medio ambiental, (Thesis for specialist degree in Tax Auditing and Management) School of Economic and Managerial Sciences, University of Bogota, Colombia.

Claver, E., López, M. D., \& Molina, J.F. (2007). Los Stakeholders y la actitud medioambiental de los directivos. Un estudio Qual/Quan., [Conference presentation] Congreso anual de AEDEM, Madrid, Spain.

Colina, J., \& Senior, A. (2008). Balance social. Instrumento de análisis para la gestión empresarial responsable. Multiciencias, 8(Extraordinario), 71-77. Retrieved from https://www.redalyc.org/pdf/904/90411691010.pdf

Colmenares, L., Valderrama, Y., \& Adriani, R. (2015). Representación contable desde la perspectiva del impacto ambiental empresarial. En el contexto del desarrollo de actividades industriales en Latinoamérica. Cuadernos De Contabilidad, 16(41). Retrieved from https://doi. org/10.11144/Javeriana.cc16-41.rcpi

Consejo Mexicano de Normas de Información Financiera. Instituto Mexicano de Contadores Públicos. (2019).
Normas Internacionales de Información Financiera 2019, Mexico: Autor.

Contreras, O. E., Talero, L. H., \& Escobar, L.Y. (2020). Sostenibilidad, stakeholders y crisis de empresa: un análisis estructurado de percepciones. Suma de negocios, 11(24), 1-9. Retrieved from https://blogs.konradlorenz.edu.co/ files/27-08-2019-rsn_1124_contreras-pacheco-w.pdf

Correa, J. A., Garcia, M. A., \& Garcia, E. (2018). CSR communication strategies of Colombian business groups: An analysis of corporate reports. Sustainability, 10(5), 1-19. https://doi.org/10.3390/su10051602

Cunha, D. R., \& Moneva, J. L. (2018). The elaboration process of the sustainability report: A case study. Revista Brasileira de Gestao de Negocios, 20(4), 533-549. DOI: 10.7819/rbgn.v0i0.3948

Déniz, J. J., \& Verona, M. C. (2015). Deconstruyendo el resultado contable convencional para diseñar un resultado contable ambiental. Contaduría y Administración, 60(3), 536- 555. https://doi.org/10.1016/j.cya.2015.05.008

Déniz, J. J., Verona, M. C., \& De la Rosa, M. E. (2019). Materialidad de los impactos sociales en la memoria de sostenibilidad. El caso del sector eólico y los pueblos indígenas en Oaxaca, Mexico. Revista Española de Financiación y Contabilidad, 48(4), 492-524. DOI: 10.1080 / 02102412.2018 .1511157

Deegan, C. (2016). Twenty-five years of social and environmental accounting research within Critical Perspectives of Accounting: Hits, misses and ways forward. Critical Perspectives on Accounting, 43(1), 65-87. https:// doi.org/10.1016/j.cpa.2016.06.005

Fogarassy, C., Neubauer, É., Mansur, H., Tangl, A., Oláh, J., \& Popp, J. The main transition management issues and the effects of environmental accounting on financial performance: With focus on cement industry. Administration and Public Management Review, 30(31), 52-53. DOI: 1024818/amp/2018.31-04.

Freeman, R. E. (1984). Strategic management: A stakeholder approach. Boston, United States: Pitman Publishing.

Freeman, R. E. (2010). Stakeholder theory: The state of the art. Cambridge, United Kingdom: Cambridge University Press. 
Gámez, L. C., Joya, R., \& García, H. G. (2017). Análisis de la presupuestación financiera medioambiental mexicana. Retos de la Dirección, 11(1), 4-20. http://scielo.sld.cu/pdf/ rdir/v11n1/rdir02117.pdf

Garrido, S. (2019). Componentes para analizar los resultados de una Contabilidad Ambiental. Proyecciones, (13), 73- 101. https://doi.org/10.24215/26185474e006

Gray, R. (1992). Accounting and environmentalism: An exploration of the challenge of gently accounting for accountability, transparency and sustainability. Accounting, Organizations and Society, 17(5), 399-425. https://doi. org/10.1016/0361-3682(92)90038-T

Gray, R., Owen, D., \& Adams, C. (1996). Accounting \& Accountability: changes and challenges in corporate social and environmental reporting. London: Prentice hall.

Hossain, M. (2019). Environmental accounting challenges of selected manufacturing enterprises in Bangladesh. Open Journal of Business and Management, 7(2), 709-727. https://doi.org/10.4236/ojbm.2019.72048

Hutchinson, C. (1992). Environmental issues: The challenge for the chief executive. Long Range Planning, 25(3), 50-59. https://doi.org/10.1016/00246301(92)90369-D

Hyo-Sook, K. (2011). A reputational approach examining publics' attributions on corporate social responsibility motives. Asian Journal of Communication, 21(1), 84-101. https://doi.org/10.1080/01292986.2010.524230

Ionescu, C. A. (2017). Integrating the environmental accounting on the information system of the economic entities. Hyperion Economic Journal, 5(2), 42-48. https:// ideas.repec.org/a/hyp/journl/v5y2017i2p42-48.html

Kumar, P., \& Firoz, M. (2019a). Accounting for Certified Emission Reductions (CERs) in India: An analysis of the disclosure and reporting practices within the financial statements. Meditari Accountancy Research, 28(2), 365389. DOI: 10.1108/MEDAR-01-2019-0428

Kumar, P., \& Firoz, M. (2019b). What drives the Voluntary Environmental Reporting (VER): An examination of CDP India Firms, Journal of Environmental Accounting and Management, 7(1), 45-57. DOI: 10.5890/ JEAM.2019.03.004

La Soa, N. (2019). Relationship between environmental financial accounting practices and corporate financial risk: Evidence from listed companies in Vietnams Securities Market, Asian Economic and Financial Review, 9(2), 285-298. DOI: 10.18488/journal. aefr.2019.92.285.298

Larramendy, E., Tellechea, P., \& Tobes, L. (2018). Investigación empírica sobre relaciones entre la información financiera y socioambiental brindada por empresas en Argentina. Escritos Contables y de Administración, 9(1), 83-102. https://dialnet.unirioja. es/servlet/articulo?codigo $=6682382$

Larrinaga, C. (1995). La relación entre las prácticas contables y el medio ambiente (Doctoral Dissertation, Department of Financial Economy and Accounting, University of Seville, Spain). Retrieved from https://core.ac.uk/download/ pdf/61545821.pdf

Larrinaga, C. (1997). Consideraciones en torno a la relación entre la Contabilidad y el medio ambiente. Revista Española de Financiación y Contabilidad, 26(93), 957-991. http:// aeca.es/old/refc_1972-2013/1997/93-4.pdf

Larrinaga, C., Moneva, J. M., \& Ortas, E. (2019). Veinticinco ańos de Contabilidad Social y Medioambiental en España: Pasado, presente y futuro. Revista Española de Finanzas y Contabilidad, 48(4), 387-405. https://doi.or g/10.1080/02102412.2019.1632020

Llena, F. (2008). El papel de la contabilidad en la gestión medioambiental de la empresa: Propuestas y evidencia empírica. Revista de Contabilidady Dirección, 7(7), 103-134. https://dialnet.unirioja.es/servlet/ articulo? codigo $=3127470$

Llull, A. (2001). Contabilidad medioambiental y desarrollo sostenible en el sector turístico (Doctoral dissertation, School of Economy, University of the Balearic Islands, Spain). Retrieved from http://hdl. handle.net/11201/2636

Macías, H. A., \& Velásquez, S. (2017). Avances de la contabilidad social y ambiental en su contexto original. Contaduria Universidad de Antioquia, 1(70), 13-41. 
https://revistas.udea.edu.co/index.php/cont/article/ view/331294

Margerison, J., Fan, M., \& Birkin, F. (2019). The prospects for environmental accounting and accountability in China. Accounting Forum, 43(3), 327-347. DOI: 10.1080/01559982.2019.1601147.

Martínez, J., Carbonell, M., \& Agüero, A. (2006). Los stakeholders y la acción social de la empresa. Madrid, Spain: Marcial Pons.

Martinez, S. S., Jimenéz, J. D. R., \& Mesa, A. P. (2019). Externalidades ambientales desde el enfoque del costo para la toma de decisiones en materia ambiental. Caso de una empresa cafetalera. Retos de la Dirección, 13(1), 170-187. Retrieved from http://scielo.sld.cu/pdf/rdir/ v13n1/2306-9155-rdir-13-01-170.pdf

Mejía, E., Montilla, O., Montes, C. A., \& Mora, G. (2015). Teoría Tridimensional de la Contabilidad. Pereira, Colombia: Universidad Libre.

Moneva, J. M., \& Llena, F. (1996). Análisis de la información sobre responsabilidad social en las empresas industriales que cotizan en bolsa. Revista Española de Financiación y Contabilidad, 25(87), 361-401. http://www.aeca.es/old/ refc_1972-2013/1996/87-3.pdf

Muralikrishna, I., \& Manickam, V. (2017). Environmental Management: Science and Engineering for Industry. In Environmental Management. Amsterdam: ButterworthHeinemann. DOI: 10.1016/B978-0-12-811989-1.00007-5

Mussa, I., Feku, A., \& Mussa, M. (2018). Environmental accounting and auditing and eco mark. Current Investigations in Agriculture and Current Research, 5(3), 612- 614. DOI: 10.32474/CIACR.2018.05.000212

Nadjoua, A., \& Bouselma, H. (2016). Obstacles to the implementation of environmental financial accounting in the Algerian cement enterprises: A field study. Dirassat, I(48), 12-23. DOI: 10.34118 / 0136-000-048-024

Nijkamp, P., Rodenburg, C., \& Verhoef, E. (1999). The adoption and diffusion of environmental friendly technologies among firms. International Journal of Technology Management, 17(4), 421-437. DOI: 10.1504 / IJTM.1999.002725
Palma, G., \& Cañizares, M. (2018). La contabilidad ambiental como herramienta de gestión para el turismo sostenible. Cofin Habana, 12(1), 124-146. http://scielo. sld.cu/pdf/cofin/v12n1/cofin09118.pdf

Parodi, P. D. (Oct., 2010). Gestión de los costos ambientales en la actividad minera. Foro Virtual de Contabilidad Ambiental y Social, Buenos Aires, Argentina. Retrieved from http://www.economicas.uba. ar/wp-content/uploads/2017/08/T_Parodi_Costos_ Ambientales_Minera.pdf

Rivera, J. A. (2019, October 20). Acciones de empresas responsables con el medio ambiente generan más valores: BMV. El Economista. Retrieved from https://www. eleconomista.com.mx/mercados/Acciones-de-empresasresponsables-con-el-medio-ambiente-generan-mas-valorBMV-20191020-0008.html

Salas, H. (2015). Integración de la dimensión ambiental al sistema de información financiero de empresas ubicadas en ecosistemas frágiles. Revista Universidad y Sociedad, 7(2), 102-109. http://scielo.sld.cu/pdf/rus/ v7n1/rus14115.pdf

Schvarstein, L. (2010). Psicología social de las organizaciones: nuevos aportes. Buenos Aires, Argentina: Paidos.

Sheshukova, T., \& Mukhina, E. (2018). Environmental accounting in digital economy. En Antipoya, T., \& Rocha, A. (Ed.). Digital Science (pp. 64-70). Coimbra, Portugal: Springer.

Smith, A. M., \& Kotzee, E. (2017). Investigating environmental management accounting in the chemical industry in South Africa. Investment Management and Financial Innovations, 13(1), 151-160. Doi:10.21511/ imfi.13(1-1).2016.02

Stefan, R. B. (2017). Contemporary environmental accounting. Issues, concepts and practice. London: Routledge. https:// doi.org/10.4324/9781351282529

Tamayo, C. D., \& Ruíz, M. C. (2018). De la responsabilidad social empresarial al balance social. Cofin Habana, 1(1), 304-320. Retrieved from http://scielo.sld.cu/pdf/cofin/ v12n1/cofin20118.pdf 
Tua, J. (1995). Lecturas de Teoría e investigación contable. Colombia: Ediciones Gráficas Ltda.

Tua, J. (2001). Normas internacionales de Contabilidad y Auditoría sobre la incidencia del medio ambiente en la información financiera. Revista Legis del Contador. Colombia, 1(7), 117-166. Retrieved from https://biblat. unam.mx/es/revista/revista-legis-del-contador/2
Uribe, A., \& Requena, R. (2013). Consideraciones del enfoque stakeholder. Punto de vista, 4(7), 31-50. Retrieved from https://dialnet.unirioja.es/ejemplar/372154

Vilela, P. D. (2017). La contabilidad financiera ambiental en las empresas agrícolas ecuatorianas. Revista Cientifica Retos de la Ciencia, 1(1), 72-87. http://retosdelaciencia. com/Revistas/index.php/retos/article/view/144 


\section{Appendix A}

Tool used to identify the use of EFA in the sustainability and financial reports of the companies studied. Number "1" means that EFA is being applied, whereas " 0 " means there is no evidence of its application. The elements that were analyzed are those listed by Llull $(2001$, p.1) in the definition of the concepts that make up EFA: "records and information on environmental assets, liabilities, expenditure, income, contingencies, and provisions."

\begin{tabular}{|c|c|c|c|c|c|}
\hline Business sector & $\begin{array}{l}\text { Aspects of } \\
\text { environmental } \\
\text { financial } \\
\text { accounting/ } \\
\text { companies }\end{array}$ & $\begin{array}{l}\text { Environmental } \\
\text { activity report } \mathrm{v}_{2.1} \\
(\mathrm{EAR})\end{array}$ & $\begin{array}{c}\text { Environmental } \\
\text { provisions and } \\
\text { liabilities report } \mathrm{v}_{2.2} \\
\text { (EPLR) }\end{array}$ & $\begin{array}{c}\text { Environmental } \\
\text { expenditure and } \\
\text { investment report } \\
\mathbf{v}_{2.3}(\mathrm{EEIR})\end{array}$ & $\begin{array}{l}\text { Environmental/ } \\
\text { social report } \mathbf{v}_{2.4} \\
\quad(\text { ESR) }\end{array}$ \\
\hline \multirow[t]{3}{*}{ TS } & América Móvil & 1 & 1 & 1 & 0 \\
\hline & Grupo Televisa & 1 & 1 & 1 & 1 \\
\hline & AXTEL & 1 & 0 & 1 & 1 \\
\hline \multirow[t]{6}{*}{ I } & $\begin{array}{c}\text { Grupo Aeroportuario } \\
\text { del Sureste }\end{array}$ & 1 & 1 & 1 & 1 \\
\hline & ALFA & 1 & 1 & 1 & 1 \\
\hline & $\begin{array}{c}\text { Grupo Aeroportuario } \\
\text { del Centro Norte }\end{array}$ & 1 & 0 & 1 & 1 \\
\hline & $\begin{array}{c}\text { Corporación } \\
\text { Inmobiliaria VESTA }\end{array}$ & 1 & 0 & 1 & 0 \\
\hline & $\begin{array}{l}\text { Controladora Vuela } \\
\text { Compañía de } \\
\text { Aviación }\end{array}$ & 1 & 0 & 1 & 0 \\
\hline & $\begin{array}{l}\text { Orbia Advance } \\
\text { Corporation }\end{array}$ & 1 & 0 & 1 & 1 \\
\hline \multirow[t]{3}{*}{ M } & CEMEX & 1 & 1 & 1 & 1 \\
\hline & Grupo México & 1 & 0 & 1 & 0 \\
\hline & Industrias Peñoles & 1 & 1 & 1 & 1 \\
\hline \multirow[t]{3}{*}{ CD\&S } & Grupo Elektra & 1 & 1 & 1 & 0 \\
\hline & ALSEA & 1 & 0 & 0 & 0 \\
\hline & Hoteles City Express & 1 & 0 & 1 & 1 \\
\hline \multirow[t]{8}{*}{ CS } & $\begin{array}{l}\text { Fomento Económico } \\
\text { Mexicano (FEMSA) }\end{array}$ & 1 & 0 & 1 & 1 \\
\hline & $\begin{array}{l}\text { Coca-Cola FEMSA } \\
\text { (COF) }\end{array}$ & 1 & 0 & 1 & 0 \\
\hline & $\begin{array}{l}\text { Wal - Mart de } \\
\text { México }\end{array}$ & 1 & 0 & 1 & 0 \\
\hline & Arca Continental & 1 & 0 & 1 & 0 \\
\hline & Grupo Bimbo & 1 & 0 & 1 & 1 \\
\hline & Grupo Herdez & 1 & 0 & 1 & \\
\hline & $\begin{array}{c}\text { Kimberly - Clark De } \\
\text { México }\end{array}$ & 1 & 0 & 1 & 1 \\
\hline & Grupo LALA & 1 & 0 & 1 & 1 \\
\hline
\end{tabular}

TS = Telecommunication services, $\mathrm{I}=$ Industrial, $\mathrm{M}=$ Materials, $\mathrm{CD} \& \mathrm{~S}=$ Consumer discretionary $\&$ services $\mathrm{CS}$, = Consumer staples $\mathrm{F}=$ Financial services, $\mathrm{E}=$ Energy, $\mathrm{HC}=$ Healthcare, $\mathrm{EAC}=$ Environmental activity report, $\mathrm{EPLR}=$ Environmental provisions and liabilities report, EEIR = Environmental expenditure and liabilities report, ESB = Environmental/social report, 1 = Identified, $2=$ Not identified

Source: Elaborated by the authors. 
Continued...

\begin{tabular}{|c|c|c|c|c|c|}
\hline Business sector & $\begin{array}{l}\text { Aspects of } \\
\text { environmental } \\
\text { financial } \\
\text { accounting/ } \\
\text { companies }\end{array}$ & $\begin{array}{l}\text { Environmental } \\
\text { activity report } \mathrm{v}_{2.1} \\
(\mathrm{EAR})\end{array}$ & $\begin{array}{c}\text { Environmental } \\
\text { provisions and } \\
\text { liabilities report } \mathrm{v}_{2.2} \\
(\mathrm{EPLR})\end{array}$ & $\begin{array}{c}\text { Environmental } \\
\text { expenditure and } \\
\text { investment report } \\
\mathbf{v}_{2.3}(\text { EEIR) }\end{array}$ & $\begin{array}{l}\text { Environmental/ } \\
\text { social report } \mathbf{v}_{2.4} \\
\quad(E S R)\end{array}$ \\
\hline \multirow[t]{4}{*}{ FS } & $\begin{array}{c}\text { Grupo Financiero } \\
\text { Banorte }\end{array}$ & 1 & 0 & 1 & 1 \\
\hline & $\begin{array}{c}\text { Bolsa Mexicana de } \\
\text { Valores }\end{array}$ & 1 & 0 & 1 & 1 \\
\hline & GENTERA & 1 & 0 & 0 & 1 \\
\hline & $\begin{array}{l}\text { Banco Santander } \\
\text { México, S.A., } \\
\text { Institución De Banca } \\
\text { Múltiple, Grupo } \\
\text { Financiero Santander }\end{array}$ & 1 & 0 & 1 & 1 \\
\hline $\mathrm{E}$ & $\begin{array}{l}\text { Infraestructura } \\
\text { Energética Nova }\end{array}$ & 1 & 1 & 1 & 1 \\
\hline $\mathrm{HC}$ & $\begin{array}{c}\text { Genomma Lab } \\
\text { Internacional }\end{array}$ & 1 & 0 & 1 & 1 \\
\hline Totales & & $\mathrm{Si}=29 \mathrm{No}=0$ & $\mathrm{Si}=8 \mathrm{No}=21$ & $\mathrm{Si}=27 \mathrm{No}=2$ & $\mathrm{Si}=20 \mathrm{No}=9$ \\
\hline
\end{tabular}

TS = Telecommunication services, $\mathrm{I}=$ Industrial, $\mathrm{M}=$ Materials, CD\&S = Consumer discretionary \& services CS, = Consumer staples $\mathrm{F}=$ Financial services, $\mathrm{E}=$ Energy, $\mathrm{HC}=$ Healthcare, $\mathrm{EAC}=$ Environmental activity report, EPLR = Environmental provisions and liabilities report, EEIR = Environmental expenditure and liabilities report, ESB = Environmental/social report, $1=$ Identified, $2=$ Not identified

Source: Elaborated by the authors. 


\section{Copyrights:}

RBGN owns the copyrights of this published content.

\section{Plagiarism analysis}

RBGN performs plagiarism analysis on all its articles at the time of submission and after approval of the manuscript using the iThenticate tool.

\section{Authors:}

1. Saulo Sinforoso Martínez, PhD in Administrative Sciences and Management for Development by the University of Veracruz, Veracruz, Mexico.

E-mail: ssinforoso@uv.mx

2. Arístides Pelegrin Mesa, PhD in Accounting Sciences by the University of Camagüey Ignacio Agramonte y Loynaz, Camaguey, Cuba.

E-mail: pelegrin65@yahoo.es

\section{Authors' Contributions}

Saulo Sinforoso Martínez: Definition of research problem; Development of hypotheses or research questions (empirical studies); Development of theoretical propositions (theoretical work); Theoretical foundation/literature review; Analysis and interpretation of data; Data collection; Statistical analysis; Analysis and interpretation of data; Manuscript writing.

Arístides Pelegrin Mesa: Development of theoretical propositions (theoretical work); Theoretical foundation/literature review; Critical revision of the manuscript; Statistical analysis; Analysis and interpretation of data; Manuscript writing. 